\title{
PENGARUH KUALITAS AKTIVA PRODUKTIF DAN KECUKUPAN MODAL TERHADAP RENTABILITAS PADA BANK MEGA SYARIAH
}

\author{
Oleh: \\ H. Tb. Aman Faturachman \\ (Dosen Program Studi Akuntansi Fakultas Pendidikan Ekonomi \& Bisnis UPI BHMN Bandung) \\ Hajar Yuhanida Alhaq \\ (Alumni Program Studi Akuntansi Fakultas Pendidikan Ekonomi \& Bisnis UPI BHMN Bandung)
}

\begin{abstract}
Abstrak
Penelitian dilakukan untuk mengetahui gambaran tingkat kualitas aktiva produktif dan kecukupan modal Bank Mega Syariah serta gambaran tingkat rentabilitas Bank Mega Syariah. Selain itu juga untuk mengetahui pengaruh kualitas aktiva produktif dan kecukupan modal terhadap rentabilitas. Metode yang digunakan dalam penelitian ini adalah metode deskriptif dan verifikatif. Sumber data penelitian yang digunakan adalah sumber data sekunder. Pengujian hipotesis menggunakan teknik analisis regresi berganda, korelasi parsial, korelasi berganda, dan koefisien determinasi. Hasil penelitian menunjukkan bahwa kualitas aktiva produktif berpengaruh positif terhadap rentabilitas secara parsial, dengan tingkat pengaruh sebesar $25,6 \%$. Sedangkan kecukupan modal berpengaruh negatif terhadap rentabilitas secara parsial, dengan tingkat pengaruh sebesar $13 \%$. Serta kualitas aktiva produktif dan kecukupan modal berpengaruh positif secara simultan terhadap rentabilitas, dengan tingkat pengaruh sebesar $38 \%$. Penulis menyarankan agar Bank Mega Syariah harus tetap memegang prinsip kehatian-hatian (prudent approach) dalam penyaluran dana pembiayaannya karena melalui prinsip tersebut dana yang dikeluarkan melalui pembiayaan tersebut dapat tepat sasaran, return yang diperoleh sebanding dengan pembiayaan yang disalurkan dan tidak mengalami risiko pembiayaan yang tinggi.
\end{abstract}

Kata kunci : Kualitas Aktiva Produktif dan Kecukupan Modal

\section{Latar Belakang Penelitian}

Masalah rentabilitas merupakan hal yang sangat penting bagi suatu perusahaan karena suatu perusahaan haruslah berada dalam keadaan yang menguntungkan atau profitable. Tanpa adanya keuntungan akan sangat sulit bagi perusahaan untuk melakukan kegiatan operasional usahanya. Maka para stakeholder suatu perusahaan akan berusaha untuk meningkatkan keuntungannya karena keuntungan merupakan hal yang penting bagi kelangsungan hidup suatu perusahaan.

Salah satu bank umum syariah yang beroperasi di Indonesia adalah PT. Bank Mega Syariah Indonesia, Tbk. Bank Mega Syariah Indonesia merupakan hasil akuisisi dari PT. Bank Umum Tugu oleh Para Group (PT. Para Global Investindo dan PT. Para Rekan Investama) untuk dikembangkan menjadi bank syariah pada tanggal pada 25 Agustus 2004. Adapun perkembangan rentabilitas Bank Mega Syariah dari tahun 2007 sampai dengan tahun 2008 dalam bentuk triwulan berdasarkan ROE (Return On Equity) sebagai berikut. 
Perkembangan Rentabilitas Bank Mega Syariah Berdasarkan Return on Equity (ROE) Pada Tahun 2007-2008

\begin{tabular}{|c|c|c|c|}
\hline $\begin{array}{c}\text { TAH } \\
\text { UN }\end{array}$ & TRIWULAN & ROE & PERUBAHAN \\
\hline \multirow[t]{4}{*}{2007} & I & $89,83 \%$ & Naik \\
\hline & II & $60,70 \%$ & Turun \\
\hline & III & $61,84 \%$ & Naik \\
\hline & IV & $57,99 \%$ & Turun \\
\hline \multirow[t]{2}{*}{2008} & I & $43,45 \%$ & Turun \\
\hline & II & $32,00 \%$ & Turun \\
\hline
\end{tabular}

Sumber: Laporan Keuangan Bank Mega Syariah

Faktor-faktor yang mempengaruhi rentabilitas bank syariah antara lain perubahan jumlah aktiva produktif, kualitas aktiva produktif, efisiensi, dan nilai tukar. Faktor-faktor tersebut memiliki proporsi pengaruh yang berbeda-beda terhadap rentabilitas.

Salah satu faktor yang menyebabkan turunnya rentabilitas Bank Mega Syariah Indonesia adalah kualitas aktiva produktif. Penilaian terhadap kualitas aktiva produktif didasarkan pada tingkat kolektibilitasnya, yaitu ketepatan pembayaran kembali angsuran serta kemampuan debitur baik ditinjau dari usaha maupun nilai agunan yang bersangkutan.

Dalam penyaluran aktiva produktif bank bisa saja mengalami hambatan dalam kolektibilitas apabila terjadi pembiayaan bermasalah (Non Perfoming Financing), maka dalam menjalankan operasionalnya bank harus menerapkan prinsip kehati-hatian (Prudent Approach) dalam menentukan kualitas aktiva produktifnya. Hal ini sesuai dengan Peraturan Bank Indonesia Nomor: 9/9/PBI/2007 yang menetapkan ketentuan bahwa kelangsungan usaha bank yang melaksanakan kegiatan usaha berdasarkan prinsip syariah tergantung dari kemampuan dalam melakukan penanaman dana dengan mempertimbangkan risiko dan prinsip kehati-hatian berupa pemenuhan kualitas aktiva dan penyisihan penghapusan aktiva yang memadai, dan kewajiban penilaian kualitas aktiva dan pembentukan penyisihan penghapusan aktiva perlu diberlakukan terhadap aktiva produktif dan aktiva non produktif.

Mengacu pada prinsip kehati-hatian tersebut bank syariah harus mempertahankan kualitas aktiva seproduktif mungkin. Dalam hal ini bank senantiasa berusaha agar aktiva produktif yang sudah disalurkan bisa memiliki tingkat pengembalian atau kolektibilitas yang lancar sehingga bisa mendukung rentabilitas atau laba yang diperoleh oleh bank.

Setiap penciptaan aktiva yang dilakukan oleh bank, disamping berpotensi memperoleh laba juga berpotensi terjadinya risiko. Maka untuk menutupi risiko tersebut bank memerlukan modal. Karena salah satu fungsi modal adalah untuk menyerap kerugian yang ditimbulkan dari risiko suatu aktiva. Maka semakin besar penciptaan aktiva yang dilakukan oleh suatu bank, semakin besar juga modal yang dibutuhkan, dan begitu pula sebaliknya. 
Berdasarkan dengan prinsip kehati-hatian BI mengeluarkan peraturan No. 10/15/PBI/2008 tentang Kewajiban Penyediaan Modal Minimum Bank Umum, besarnya modal minimum yang harus dimiliki oleh setiap bank adalah sebesar $8 \%$ (delapan persen) dari Aktiva Tertimbang Menurut Risiko (ATMR). Angka ini merupakan penyesuaian dari ketentuan yang berlaku secara internasional berdasarkan ketentuan bank for international settlement (BIS). Penyesuaian ini diharapkan agar Indonesia mampu bersaing dalam persaingan perdagangan bebas dunia. Pedoman ini dikeluarkan oleh BIS dengan tetap mempertimbangkan kondisi Negara.

Namun antara kecukupan modal (CAR) dengan kemampuan bank dalam memperoleh laba (ROE) terdapat suatu trade-off. Adanya trade-off ini didasarkan pada penjelasan Dahlan Siamat (2004:103) yang mengemukakan bahwa : "...dalam menentukan jumlah modal, manajemen bank harus memutuskan seberapa besar tingkat keuntungan yang dapat diperoleh dengan kenaikan jumlah modal, sementara kenaikan modal tersebut akan dapat menurunkan ROE akibat naiknya permodalan bank. Korelasi ini merupakan trade off antara sisi keamanan dan keuntungan bagi pemegang saham bank. Dalam keadaan di mana kemungkinan bank akan mengalami kondisi sulit akibat terdapatnya aktiva produktif bank yang bermasalah (nonperforming asset) dalam jumlah besar maka manajemen akan cenderung menambah modal. Namun apabila ia yakin bahwa tidak akan timbul kerugian akibat terjadi kredit bermasalah, bank akan mengurangi jumlah modal untuk meningkatkan equity multipliernya yang pada gilirannya akan meningkatkan ROE".

\section{Rumusan Masalah}

1. Bagaimana kualitas aktiva produktif pada Bank Mega Syariah periode tahun 20042008 .

2. Bagaimana kecukupan modal pada Bank Mega Syariah periode tahun 2004-2008 .

3. Bagaimana rentabilitas pada Bank Mega Syariah periode tahun 2004-2008

4. Bagaimana pengaruh kualitas aktiva produktif dan kecukupan modal terhadap rentabilitas pada Bank Mega Syariah periode tahun 2004-2008.

\section{Kerangka Pemikiran}

Bank syariah pada dasarnya memiliki peran yang sama seperti bank konvensional, yaitu sebagai lembaga intermediasi. Kegiatan utama bank syariah terdiri dari kegiatan penghimpunan dana yang berada pada sisi pasiva neraca dan kegiatan pembiayaan yang berada pada sisi aktiva neraca. Dana yang telah dihimpun oleh bank syariah kemudian disalurkan kembali melalui penciptaan aktiva produktif. Aktiva produktif merupakan semua aktiva dalam rupiah dan valuta asing yang dimiliki bank dengan maksud untuk memperoleh penghasilan sesuai dengan fungsinya.

Komponen aktiva produktif tersebut meliputi : (1) pembiayaan atau pemberian fasilitas penyediaan dana untuk memenuhi kebutuhan pihak-pihak yang merupakan defisit unit, (2) penempatan dana pada bank lain yang antara lain dalam bentuk giro atau tabungan mudharabah atau wadiah, deposito berjangka atau tabungan mudharabah, serta bentuk-bentuk penempatan lainnya berdasarkan prinsip syariah, (3) surat-surat berharga yang terdiri dari obligasi syariah, sertifikat reksadana syariah, dan (4) 
penyertaan modal berupa dana bank dalam bentuk saham pada perusahaan yang bergerak di bidang keuangan syariah.

Penilaian terhadap kualitas aktiva produktif didasarkan pada tingkat kolektibilitasnya, yaitu ketepatan pembayaran kembali angsuran serta kemampuan debitur baik ditinjau dari usaha maupun nilai agunan yang bersangkutan. Menurut Moh. Ramly Faud dan M. Rustan DM (2005:288) mengemukakan bahwa, "Kualitas aktiva produktif menunjukkan sejauhmana bank memelihara kualitas aktivanya seproduktif mungkin sehingga menjamin hasil yang mendukung rentabilitas".

Dalam penyaluran aktiva produktif bank bisa saja mengalami hambatan dalam kolektibilitas apabila terjadi pembiayaan bermasalah (Non Perfoming Financing), maka dalam menjalankan operasionalnya bank harus menerapkan prinsip kehati-hatian (Prudent Approach) dalam menentukan kualitas aktiva produktifnya. Hal ini sesuai dengan Peraturan Bank Indonesia Nomor: 9/9/PBI/2007 yang menetapkan ketentuan bahwa kelangsungan usaha bank yang melaksanakan kegiatan usaha berdasarkan prinsip syariah tergantung dari kemampuan dalam melakukan penanaman dana dengan mempertimbangkan risiko dan prinsip kehati-hatian berupa pemenuhan kualitas aktiva dan penyisihan penghapusan aktiva yang memadai, dan bahwa kewajiban penilaian kualitas aktiva dan pembentukan penyisihan penghapusan aktiva perlu diberlakukan terhadap aktiva produktif dan aktiva non produktif.

Mengacu pada prinsip kehati-hatian tersebut bank syariah harus mempertahankan kualitas aktiva seproduktif mungkin. Dalam hal ini bank senantiasa berusaha agar aktiva produktif yang sudah disalurkan bisa memiliki tingkat pengembalian atau kolektibilitas yang lancar sehingga bisa mendukung rentabilitas atau laba yang diperoleh oleh bank.

Setiap penciptaan aktiva yang dilakukan oleh bank, disamping berpotensi memperoleh laba juga berpotensi terjadinya risiko. Maka untuk menutupi risiko tersebut bank memerlukan modal. Karena salah satu fungsi modal adalah untuk menyerap kerugian yang ditimbulkan dari risiko suatu aktiva. Maka semakin besar penciptaan aktiva yang dilakukan oleh suatu bank, semakin besar juga modal yang dibutuhkan, dan begitu pula sebaliknya. Hal ini senada dengan apa yang dijelaskan oleh Muhammad (2004:102) yang menyatakan bahwa:

"Setiap penciptaan aktiva yang dilakukan oleh bank, disamping berpotensi memperoleh laba juga berpotensi terjadinya risiko. Oleh sebab itu, modal dapat digunakan untuk menjaga kemungkinan risiko yang timbul atas kerugian investasi terutama yang berasal dari dana pihak ketiga atau masyarakat. Peningkatan peran aktiva sebagai penghasil keuntungan harus dibarengi dengan pertimbangan risiko yang mungkin timbul guna melindungi kepentingan pemilik dana".

Karena modal merupakan faktor yang penting dalam upaya pengembangan usaha bank. Maka Bank Indonesia sebagai otoritas moneter menetapkan ketentuan mengenai kewajiban penyediaan modal minimum yang harus selalu dipertahankan setiap bank. Ketentuan pemenuhan permodalan minimum bank disebut juga Capital Adequacy Ratio (CAR), yaitu sebesar 8\% dari Aktiva Tertimbang Menurut Risiko (ATMR). Angka ini merupakan penyesuaian dari ketentuan yang berlaku secara internasional berdasarkan ketentuan bank for international settlement (BIS). 
Penyesuaian ini diharapkan agar Indonesia mampu bersaing dalam persaingan perdagangan bebas dunia. Pedoman ini dikeluarkan oleh BIS dengan tetap mempertimbangkan kondisi Negara.

Maka dalam keadaan di mana kemungkinan bank akan mengalami kondisi sulit akibat tidak sehatnya kualitas aktiva produktifnya, manajemen akan cenderung menambah modal usahanya. Namun penambahan modal tersebut cenderung akan menurunkan tingkat kemampuan bank dalam memperoleh laba, sehingga pada akhirnya akan mempengaruhi kelangsungan hidup bank tersebut.

Hal ini didasarkan pada penjelasan Dahlan Siamat (2004:103) yang mengemukakan bahwa:

"...dalam menentukan jumlah modal, manajemen bank harus memutuskan seberapa besar tingkat keuntungan yang dapat diperoleh dengan kenaikan jumlah modal, sementara kenaikan modal tersebut akan dapat menurunkan ROE akibat naiknya permodalan bank. Korelasi ini merupakan trade off antara sisi keamanan dan keuntungan bagi pemegang saham bank. Dalam keadaan di mana kemungkinan bank akan mengalami kondisi sulit akibat terdapatnya aktiva produktif bank yang bermasalah (nonperforming asset) dalam jumlah besar maka manajemen akan cenderung menambah modal. Namun apabila ia yakin bahwa tidak akan timbul kerugian akibat terjadi kredit bermasalah, bank akan mengurangi jumlah modal untuk meningkatkn equity multipliernya yang pada gilirannya akan meningkatkan ROE".

\section{Metode Penelitian}

Metode penelitian yang digunakan dalam penelitian ini adalah deskriptif dan verifikatif. Melalui metode penelitian deskriptif, maka dapat diperoleh deskripsi mengenai perkembangan kualitas aktiva produktif dan kecukupan modal serta perkembangan rentabilitas pada Bank Mega Syariah. Penelitian verifikatif pada dasarnya ingin menguji kebenaran dari suatu hipotesis yang dilaksanakan melalui pengumpulan data di lapangan, dimana dalam penelitian ini penelitian verifikatif bertujuan untuk mengetahui pengaruh kualitas aktiva produktif dan kecukupan modal terhadap rentabilitas.

Sumber data sekunder yang digunakan dalam penelitian ini adalah data laporan keuangan publikasi PT Bank Syariah Mega Indonesia Tbk., yaitu dari tahun 2004 sejak awal berdirinya Bank Mega Syariah sampai triwulan II tahun 2008. Adapun yang menjadi pertimbangan dalam mengambil data penelitian tahun 2004 sampai triwulan II tahun 2008 adalah karena pada periode tersebut telah ditemukan suatu fenomena bahwa rentabilitas (ROE) bank cenderung mengalami penurunan.

Langkah pertama dalam menganalisis data yaitu mengumpulkan data mengenai kualitas aktiva produktif, kecukupan modal, dan rentabilitas. Setelah data terkumpul, dilakukan uji normalitas data, hal tersebut dilakukan untuk memenuhi asumsi dasar jika menggunakan statistik parametrik. Apabila data tersebut normal kemudian dilakukan analisis regresi ganda, korelasi parsial, korelasi berganda, dan analisis determinasi. 


\section{Hasil Penelitian}

Pengujian Regresi Ganda

\section{Coefficients(a)}

\begin{tabular}{|cc|c|c|c|c|c|}
\hline \multirow{2}{*}{ Model } & & \multicolumn{2}{|c|}{$\begin{array}{c}\text { Unstandardized } \\
\text { Coefficients }\end{array}$} & $\begin{array}{c}\text { Standardized } \\
\text { Coefficients }\end{array}$ & $t$ & Sig. \\
\cline { 2 - 7 } & B & $\begin{array}{c}\text { Std. } \\
\text { Error }\end{array}$ & Beta & B & $\begin{array}{c}\text { Std. } \\
\text { Error }\end{array}$ \\
\hline 1 & (Constant) & $\begin{array}{c}- \\
161,9 \\
81\end{array}$ & 102,106 & & $-1,586$ &, 139 \\
& KAP & $\begin{array}{c}209,5 \\
73\end{array}$ & 95,320 &, 500 & 2,199 &, 048 \\
CAR & $\begin{array}{c}1,889 \\
\text { C. }\end{array}$ & 1,218 &,- 353 & $-1,551$ &, 147 \\
\hline
\end{tabular}

Berdasarkan hasil perhitungan regresi ganda dengan menggunakan SPSS versi 15 diketahui bahwa pada tabel coefficients kolom unstandardized coefficients diatas ditunjukkan nilai $a=-161,981, b_{1}=209,573$, dan $b_{2}=-1,889$. Sehingga persamaan regresi yang didapat adalah $\hat{Y}=-161,981+209,573 X 1-1,889 X 2$.

Koefisien Korelasi Parsial

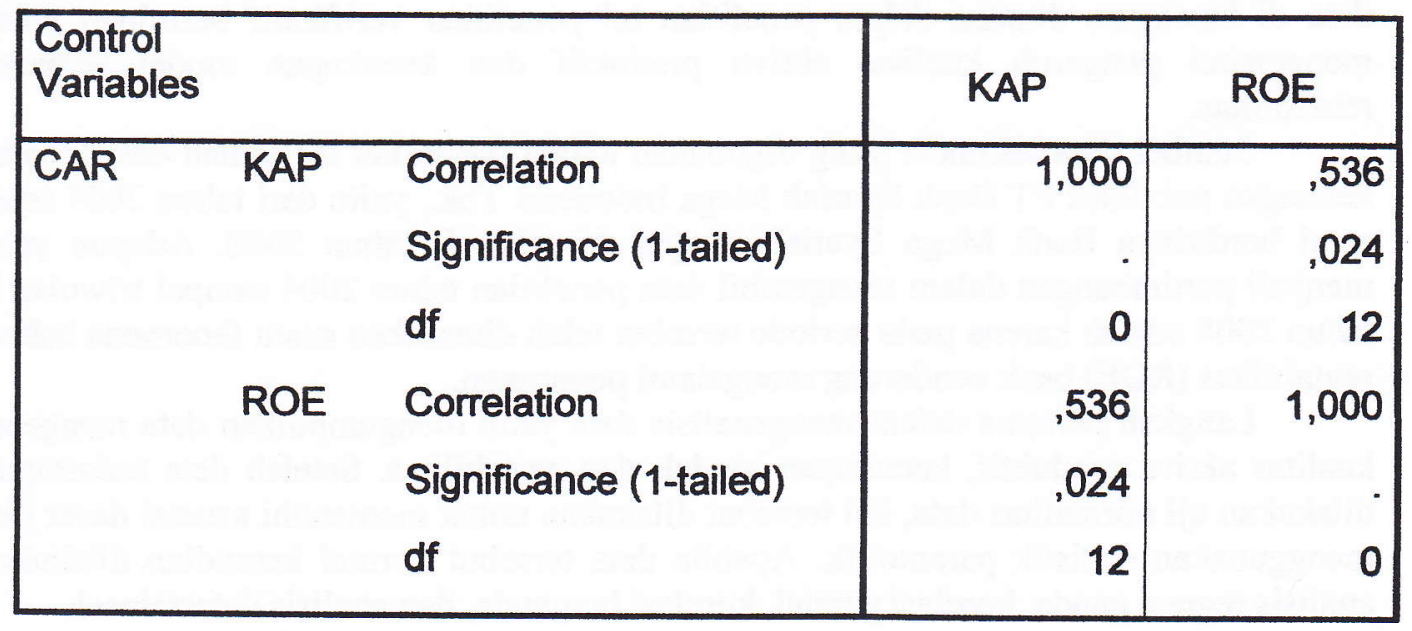


Berdasarkan hasil perhitungan SPSS versi 15 diatas, maka diperoleh nilai koefisien korelasi antara kualitas aktiva produktif dan rentabilitas bila kecukupan modal (CAR) dianggap konstan adalah sebesar 0,536.

\section{Correlations}

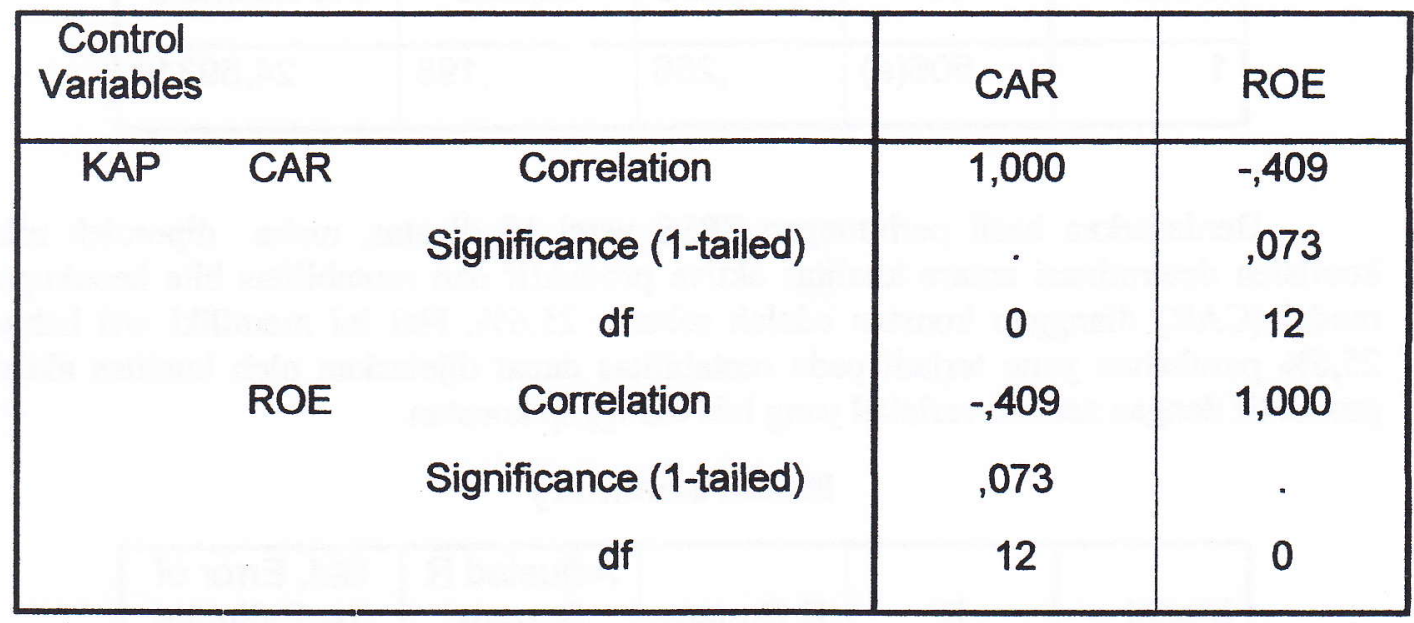

Berdasarkan hasil perhitungan SPSS versi 15 diatas, maka diperoleh nilai koefisien korelasi antara kecukupan modal dan rentabilitas bila kualitas aktiva produktif dianggap konstan adalah sebesar $-0,409$. Berdasarkan tabel interpretasi koefisien korelasi pada tabel 3.2, nilai tersebut menunjukkan adanya hubungan cukup kuat antara kecukupan modal dengan rentabilitas.

Pengujian Koefisien Korelasi Berganda

Model Summary

\begin{tabular}{|l|r|r|r|r|}
\hline Model & \multicolumn{1}{|c|}{$\mathrm{R}$} & $\mathrm{R}$ Square & $\begin{array}{c}\text { Adjusted R } \\
\text { Square }\end{array}$ & $\begin{array}{c}\text { Std. Error of } \\
\text { the Estimate }\end{array}$ \\
\hline 1 &, $616(\mathrm{a})$ &, 380 &, 277 & 23,36198 \\
\hline
\end{tabular}

Berdasarkan hasil perhitungan di atas, diperoleh angka 0,616 dengan nilai korelasi antara kecukupan modal dan kualitas aktiva produktif secara bersama-sama dengan rentabilitas adalah positif. Berdasarkan tabel interpretasi koefisien korelasi pada tabel 3.2, nilai tersebut menunjukkan adanya hubungan kuat antara kualitas aktiva produktif dengan rentabilitas. 
Koefisien Determinasi

Model Summary

\begin{tabular}{|l|r|r|r|r|}
\hline Model & R & R Square & $\begin{array}{c}\text { Adjusted R } \\
\text { Square }\end{array}$ & $\begin{array}{c}\text { Std. Error of } \\
\text { the Estimate }\end{array}$ \\
\hline 1 &, $506(a)$ &, 256 &, 198 & 24,59314 \\
\hline
\end{tabular}

Berdasarkan hasil perhitungan SPSS versi 15 di atas, maka diperoleh nilai koefisien determinasi antara kualitas aktiva produktif dan rentabilitas bila kecukupan modal (CAR) dianggap konstan adalah sebesar $25,6 \%$. Hal ini memiliki arti bahwa $25,6 \%$ perubahan yang terjadi pada rentabilitas dapat dijelaskan oleh kualitas aktiva produktif dengan asumsi variabel yang lain dianggap konstan.

Model Summary

\begin{tabular}{|l|r|r|r|r|}
\hline Model & \multicolumn{1}{|c|}{$\mathrm{R}$} & $\mathrm{R}$ Square & $\begin{array}{c}\text { Adjusted R } \\
\text { Square }\end{array}$ & $\begin{array}{c}\text { Std. Error of } \\
\text { the Estimate }\end{array}$ \\
\hline 1 &, $361(\mathrm{a})$ &, 130 &, 063 & 26,58461 \\
\hline
\end{tabular}

Berdasarkan hasil perhitungan SPSS versi 15 di atas, maka diperoleh nilai koefisien determinasi antara kecukupan modal dan rentabilitas bila kualitas aktiva produktif dianggap konstan adalah sebesar $13 \%$. Hal ini memiliki arti bahwa $13 \%$ perubahan yang terjadi pada rentabilitas dapat dijelaskan oleh kecukupan modal dengan asumsi variabel yang lain dianggap konstan.

\section{Model Summary}

\begin{tabular}{|l|r|r|r|r|}
\hline Model & R & R Square & $\begin{array}{c}\text { Adjusted R } \\
\text { Square }\end{array}$ & $\begin{array}{c}\text { Std. Error of } \\
\text { the Estimate }\end{array}$ \\
\hline 1 &, $616(a)$ &, 380 &, 277 & 23,36198 \\
\hline
\end{tabular}

Koefisien determinasi dari data di atas adalah sebesar $38 \%$. Hal ini berarti bahwa kualitas aktiva produktif dan kecukupan modal mempunyai pengaruh sebesar $38 \%$ terhadap rentabilitas. 
Pembahasan

Kualitas Aktiva Produktif PT. Bank Syariah Mega Indonesia

PT Bank Syariah Mega Indonesia merupakan salah satu bank umum yang menjalankan kegiatan usahanya berlandaskan pada prinsip hukum atau syariah islam untuk menilai tingkat kesehatannya juga melakukan penilaian terhadap kualitas aktiva produktifnya.

Berdasarkan deskripsi data variabel sebelumnya, Rasio kualitas aktiva produktif (KAP) Bank Mega syariah tahun 2004 sampai dengan triwulan II tahun 2008 berkisar antara 1 sampai dengan 1,184001. Secara keseluruhan, rata-rata kualitas aktiva produktif sebesar 1,05148. KAP tertinggi diperoleh pada triwulan II tahun 2007 sebesar 1,184001 sedangkan KAP terendah terjadi pada tahun 2004 sebesar 1.

Kondisi kualitas aktiva produktif selama tahun 2004 sampai dengan triwulan kedua tahun 2008 berada pada kondisi yang sehat. Kondisi yang sehat ini menunjukkan bahwa Bank Mega Syariah telah berusaha untuk terus meningkatkan dalam memelihara kualitas aktiva seproduktif mungkin.

\section{Kecukupan Modal PT. Bank Syariah Mega Indonesia}

Setiap penciptaan aktiva yang dilakukan oleh bank, disamping berpotensi memperoleh laba juga berpotensi terjadinya risiko. Oleh sebab itu, modal dapat digunakan untuk menjaga kemungkinan risiko yang timbul atas kerugian investasi terutama yang berasal dari dana pihak ketiga atau masyarakat. Jumlah modal minimum atau kecukupan modal yang harus dimiliki oleh bank dapat dihitung dengan menggunakan Capital Adequacy Ratio (CAR) atau rasio kecukupan modal.

Kecukupan modal yang dimiliki PT. Bank Syariah Mega Indonesia dapat diketahui bahwa kondisi CAR cenderung fluktuatif. Hal ini ditunjukkan nilai CAR terendah dicapai pada triwulan IV tahun 2006 dikarenakan meningkatnya jumlah ATMR yang mengindikasikan bahwa jumlah aktiva Bank Mega Syariah meningkat. Sedangkan nilai CAR tertinggi terjadi pada triwulan I tahun 2005 dikarenakan jumlah modal bank mengalami peningkatan, sedangkan jumlah ATMR bank mengalami penurunan. Namun apabila di lihat dari awal periode sampai akhir periode yang diteliti maka nilai CAR selama periode tersebut berada pada trend yang meningkat. Sementara rata-rata CAR bank tersebut masih berada di atas ketetapan Bank Indonesia yang menetapkan bahwa penyediaan modal minimum setiap bank adalah sebesar $8 \%$.

\section{Rentabilitas PT. Bank Syariah Mega Indonesia}

Rasio ROE tertinggi yang dicapai Bank Mega Syariah adalah pada periode triwulan I tahun 2007 sebesar $\mathbf{8 9 , 8 3 \%}$ sedangkan ROE terendah terjadi pada triwulan IV tahun 2005 sebesar 4,87\%. Rata-rata perolehan Return on Equity (ROE) jika dihitung dengan periode triwulanan, yaitu sebesar $32,084 \%$

Rentabilitas atau kemampuan bank untuk menghasilkan keuntungan dengan seluruh modal yang dimiliki PT. Bank Syariah Mega Indonesia dari segi ROE dapat diketahui bahwa cenderung menurun pada triwulan I tahun 2007 sampai dengan triwulan II tahun 2008. Penurunan ROE ini dipengaruhi oleh penurunan kualitas aktiva 
produktif Bank Mega Syariah pada periode tersebut, sehingga manajemen bank akan cenderung menambah modal usahanya. Namun penambahan modal tersebut cenderung akan menurunkan tingkat kemampuan bank dalam memperoleh laba, sehingga pada akhirnya akan mempengaruhi kelangsungan hidup bank tersebut.

\section{Simpulan}

1. Secara keseluruhan kualitas aktiva produktif pada Bank Mega Syariah tahun 2004 sampai dengan triwulan II tahun 2008 berfluktuatif dengan rata-rata sebesar 1,05148. KAP tertinggi dicapai pada triwulan II tahun 2007 sebesar 1,184001 sedangkan KAP terendah terjadi pada tahun 2004 sebesar 1. Pada triwulan I tahun 2007 sampai triwulan II tahun 2007 mengalami kenaikan yang sangat signifikan, hal ini disebabkan oleh kolektibilitas aktiva yang disalurkan (aktiva produktif) tergolong lancar. Sedangkan pada triwulan II tahun 2007 sampai triwulan II tahun 2008 mengalami penurunan yang dipengaruhi oleh meningkatnya aktiva produktif bermasalah. Meskipun pada periode tersebut mengalami penurunan, kualitas aktiva produktif Bank Mega Syariah masih berada pada kondisi yang sehat.

2. Selama tahun 2004 sampai dengan triwulan kedua tahun 2008 kecukupan modal pada Bank Mega Syariah berada pada trend yang meningkat dengan rata-rata kecukupan modal sebesar 13,92\%. CAR tertinggi dicapai pada triwulan I tahun 2005 sebesar 23,83\% sedangkan CAR terendah terjadi pada triwulan IV tahun 2006 sebesar 8,30\%. Selain itu, CAR Bank Mega Syariah Indonesia masih berada di atas standar yang telah ditetapkan oleh Bank Indonesia sebesar $8 \%$.

3. Selama periode tahun 2004 sampai dengan triwulan II tahun 2008 , rentabilitas berdasarkan ROE yang diperoleh Bank Mega Syariah mengalami penurunan dengan rata-rata rasio ROE Bank Mega Syariah sebesar 32,084 \%. ROE tertinggi dicapai pada triwulan I tahun 2007 sebesar 89,83\% sedangkan ROE terendah terjadi pada triwulan IV tahun 2005 sebesar 4,87\%, meskipun menurun ROE Bank Mega Syariah masih tetap berada pada kondisi yang sehat.

4. Berdasarkan hasil perhitungan statistik diketahui persamaan regresi $\hat{Y}=-161,981+209,573 X 1-1,889 X 2$, koefisien regresi bertanda positif $(+)$ yang mengandung pengertian bahwa terdapat pengaruh positif antara kualitas aktiva produktif dengan rentabilitas. Selain itu nilai korelasi parsial antara kualitas aktiva produktif dan rentabilitas bila kecukupan modal (CAR) dianggap konstan adalah sebesar 0,536 (positif) dengan tingkat pengaruh sebesar 25,6\%. Hal ini menunjukkan terdapat hubungan positif cukup kuat antara kualitas aktiva produktif dengan rentabilitas. Jadi, hipotesis "kualitas aktiva produktif berpengaruh positif terhadap rentabilitas" pada Bank Mega Syariah periode tahun 2004-triwulan II tahun 2008, diterima karena semakin sehat kualitas aktiva produktif maka akan menunjang kemampuan bank dalam memperoleh laba. Sedangkan koefisien regresi bertanda negatif $(-)$ yang mengandung pengertian bahwa terdapat pengaruh negatif antara kecukupan modal dan rentabilitas dengan nilai korelasi parsial antara kecukupan modal dan rentabilitas bila kualitas aktiva produktif dianggap konstan adalah sebesar $-0,409$ (negatif) dengan tingkat pengaruh sebesar $13 \%$. Hal ini menunjukkan adanya hubungan cukup kuat antara kecukupan modal dengan rentabilitas. Jadi, hipotesis 
"kecukupan modal berpengaruh negatif terhadap rentabilitas" pada Bank Mega Syariah periode tahun 2004-triwulan II tahun 2008, diterima karena bank akan mengalami kondisi terdapatnya aktiva produktif bermasalah maka manajemen akan cenderung menambah modal yang akan menurunkan rentabilitas bank. Sedangkan nilai korelasi antara kualitas aktiva produktif dan kecukupan modal dengan rentabilitas adalah sebesar 0,616 (positif). Hal ini menunjukkan adanya hubungan kuat antara kualitas aktiva produktif dan kecukupan modal dengan rentabilitas. Adapun hasil perhitungan koefisien determinasi diperoleh nilai sebesar 38\%. Hal ini berarti bahwa kualitas aktiva produktif dan kecukupan modal mempunyai pengaruh sebesar $38 \%$ secara simultan terhadap rentabilitas, sedangkan sisanya sebesar $62 \%$ dipengaruhi oleh faktor lain seperti jumlah aktiva produktif, nilai tukar, dan efisiensi. Jadi, hipotesis "kualitas aktiva produktif dan kecukupan modal berpengaruh positif terhadap rentabilitas" pada Bank Mega Syariah periode tahun 2004-triwulan II tahun 2008, diterima karena pengaruh kualitas aktiva produktif terhadap rentabilitas lebih kuat dibandingkan kecukupan modal.

\section{Saran}

1. Berdasarkan hasil penelitian diketahui bahwa kualitas aktiva produktif Bank Mega Syariah pada triwulan kedua tahun 2007 sampai triwulan kedua tahun 2008 mengalami trend penurunan. Hal ini disebabkan meningkatnya aktiva produktif bermasalah Bank Mega Syariah. Oleh karena itu, untuk meningkatkan kualitas aktiva produktif dan mengurangi aktiva produktif bermasalah maka pihak bank harus lebih memperhatikan analisis pembiayaan dan meningkatkan pengawasan pada saat pembiayaan berjalan.

2. Berdasarkan hasil penelitian diketahui bahwa CAR Bank Mega Syariah pada triwulan pertama tahun 2007 sampai dengan triwulan kedua tahun 2008 mengalami peningkatan. Hal ini disebabkan aktiva produktif bermasalah Bank Mega Syariah mengalami peningkatan. Besarnya risiko yang melekat pada aktiva tersebut menyebabkan pihak bank tidak bebas melakukan investasi guna mencapai tingkat laba yang diharapkan. Oleh karena itu, Bank Mega Syariah harus mengurangi aktiva yang memiliki bobot risiko yang tinggi sehingga tingkat risiko aktiva bank dapat berkurang.

3. Bank Mega Syariah harus meningkatkan kemampuan perusahaannnya dalam menghasilkan laba. Karena berdasarkan hasil penelitian rentabilitas Bank Mega Syariah cenderung menurun. Peningkatan laba tersebut dapat tercapai apabila pihak bank tetap memegang prinsip kehatian-hatian (prudent approach) dalam penyaluran dana pembiayaannya. Sehingga dana yang dikeluarkan melalui pembiayaan tersebut dapat tepat sasaran dan return yang diperoleh sebanding dengan pembiayaan yang disalurkan serta tidak mengalami risiko pembiayaan yang tinggi. 
4. Pihak-pihak yang terkait yang akan meneliti lebih dalam mengenai masalah ini disarankan untuk melakukan penelitian terhadap faktor-faktor lain yang mempengaruhi rentabilitas bank syariah, misalnya, efisiensi dan nilai tukar. Hal ini dikarenakan agar diperoleh hasil yang lebih tepat dan akurat sehingga bisa menjadi acuan prediksi bagi bank yang diteliti.

Daftar Pustaka

Adiwarman Karim. (2004). Bank Islam Analisis Fiqih dan Keuangan. Jakarta : PT Raja Grafindo Persada.

Agnes Sawir. (2005). Analisis Kinerja Keuangan dan Perencanaan Keuangan Perusahaan. Jakarta : PT Gramedia Pustaka Utama.

Arikunto. Suharsimi (2004). Prosedur Penelitian. Jakarta: Penerbit Rineka Cipta.

Bank Mega Syariah. (2008). Informasi Profile dan Laporan Keuangan Publikasi. [Online]. Tersedia : www.bankmegasyariah.co.id

Bank Indonesia. (2006). Peraturan Bank Indonesia Nomor : 8/21/PBI/2006 tentang Penilaian Kualitas Aktiva Bank Umum yang Melaksanakan Kegiatan Usaha Berdasarkan Prinsip Syariah. [Online]. Tersedia : www.bi.go.id

Bank Indonesia. (2006). Peraturan Bank Indonesia Nomor : 9/9/PBI/2007 tentang Perubahan Peraturan Nomor : 8/21/PBI/2006 Penilaian Kualitas Aktiva Bank Umum yang Melaksanakan Kegiatan Usaha Berdasarkan Prinsip Syariah. [Online]. Tersedia : www.bi.go.id

Bank Indonesia. (2008). Laporan Perkembangan Perbankan Syariah 2008. [Online]. Tersedia: www.bi.go.id

Bank Indonesia. (2005). Peraturan BI No. 10/15/PBI/2008 tentang Kewajiban Penyediaan Modal Minimum Bank Umum. [Online]. Tersedia : www.bi.go.id

Bank Indonesia. (2008). Statistik Perbankan Syariah Desember 2008. [Online]. Tersedia : www.bi.go.id

Bank Indonesia. (2007). Surat Edaran Bank Indonesia Nomor : 9/24/DPbs tanggal 30 Oktober 2007 tentang Perihal Penilaian Tingkat Kesehatan Bank Umum Berdasarkan Prinsip Syariah. [Online]. Tersedia : www.bi.go.id

Dahlan Siamat. (2004). Manajemen Lembaga Keuangan Edisi Ketiga. Jakarta: Lembaga Penerbit Fakultas Ekonomi Universitas Indonesia.

Iqbal Hasan. (2006). Analisis Data Penelitian dengan Statistik. Jakarta : Bumi Aksara.

Komaruddin Sastradipoera. Strategi Manajemen Bisnis Perbankan. Bandung: KappaSigma.

Lukman Dendawijaya. (2005). Manajemen Perbankan Edisi Kedua. Bogor: Ghalia Indonesia.

Moh. Ramly Faud \& Rustam D.M.. (2005). Akuntansi Perbankan : Petunjuk Praktis Operasional Bank. Yogyakarta : Graha Ilmu.

Mudrajad Kuncoro dan Suhardjono. (2002). Manajemen Perbankan Teori dan Aplikasi Edisi Pertama. Yogyakarta: BPFE.

Muhammad Syafi'i Antonio. (2001). Bank Syariah dari Teori ke Praktek. Jakarta: Gema Insani dan Tazkia Cendikia. 
Muhammad. (2005). Manajemen Bank Syariah. Yogyakarta: UPP AMP YPKN.

Nazir, Moh. (1999). Metode Penelitian. Jakarta: Ghalia Indonesia.

Riduwan. (2005). Rumus dan Data dalam Analisis Statistika. Bandung: CV Alfabeta.

Rina Irmayani. (2007). "Pengaruh Kualitas Aktiva Produktif terhadap Rentabilitas". Skripsi. Bandung: Jurusan Pendidikan Ekonomi Fakultas Pendidikan Ilmu Pengetahuan Sosial Universitas Pendidikan Indonesia.

Sugiyono. (2009). Metode Penelitian Administrasi. Bandung: CV Alfabeta.

Suharsimi Arikunto. (2002). Prosedur Penelitian Suatu Pendekatan Praktek. Jakarta: PT Rineka Cipta.

Undang-Undang Perbankan Syariah Nomor 21 Tahun 2008. 